\title{
Экспертиза
}

ДУБРОВИНА Ольга Юрьевна - кандидат политических наук, доцент Сибирского института международных отношений и регионоведения (630075, Россия, г. Новосибирск, ул. Народная, 14; olgadubrovina@mail.ru)

\section{СОВЕТ ГЛАВ СУБЪЕКТОВ РОССИЙСКОЙ ФЕДЕРАЦИИ ПРИ МИД РОССИИ КАК МЕХАНИЗМ КООРДИНАЦИИ МЕЖДУНАРОДНЫХ СВЯЗЕЙ РЕГИОНОВ: ИСТОРИКО-МЕТОДОЛОГИЧЕСКИЕ АСПЕКТЫ ПРОБЛЕМЫ}

Аннотация. Данная статья посвящена мало представленной в научной литературе проблеме деятельности Совета глав субъектов Российской Федерации при Министерстве иностранных дел РФ (СГС). Созданный в 2003 г., СГС является важным механизмом взаимодействия федерального центра с регионами России. Его цель - совершенствование механизма координации МСР для осуществления единой внешней политики РФ на международной арене.

В статье автор рассматривает основные направления, задачи, формы, методы и проблемы деятельности Совета, показывает результаты его работы на фоне осуществления внешней политики РФ и международных отношений.

Ключевые слова: Совет глав субъектов РФ при МИД России (СГС), международные связи регионов России (МСР), международные отношения, внешняя политика РФ, глобализация, консультативно-совещательный орган при МИД России, механизм реализации международной стратегии, механизм осуществления международных связей регионов России

И сследования международных связей регионов государств (МСР) отличаются многогранностью. В основе их многоликости лежит сложность самого объекта, находящегося в процессе постоянных изменений. Его противоречивая природа приводит к необходимости изучения общего и особенного при осуществлении международных связей регионов государств, выявления тенденций их развития. Возрастающий интерес к данной проблеме поощряется развитием самого исследовательского объекта и увеличением влияния регионов на международные отношения и внешнюю политику государств.

Изучение международных связей регионов государств еще слабо оснащено в методологическом плане. Но российские и международные исследования приближают нас к пониманию смысла происходящего в мире, вооружая знанием законов его развития и, следовательно, предвидением дальнейшей эволюции.

Современная теория международных связей регионов - преимущественно западная дисциплина. В этой сфере можно отметить ряд интересных работ [Bertalanffy 1968; Braillard, Djalili 1988; Briol 1997; Claisse 1994; Haegi 1995; Hoffmann 1961; Kaplan 1964; Michelmann 1993; Rassett, Starr 1981].

Но все же отечественные исследования в области международных связей регионов вызывают гораздо больший интерес с точки зрения представленной в них конкретной проблематики, политических оценок, анализа событий и т.п. [Бажанов, Бажанова 2011; Цыганков 2010; Василенко 2009]. Формируются научные школы и в региональных университетах [Дубровина 2011a; 2011б; 2011в; 2013a; 2013б; 2014a; 2014б; Плотникова 2014; 2015; Плотникова, Дубровина 2016а; 2016б]. Заметны и публикации молодых исследователей.

Данная статья посвящена мало представленной в научной литературе проблеме деятельности Совета глав субъектов Российской Федерации при Министерстве иностранных дел РФ (СГС), который является важным механизмом координации международных связей регионов России. 
Совет глав субъектов Российской Федерации при МИД России был создан в 2003 г. по инициативе президента РФ. В своем выступлении на заседании Государственного совета президент предложил МИДу России найти действенные механизмы сотрудничества с регионами страны. Глава государства предложил создать при МИДе России своего рода совет глав регионов [Дубровина 2011в: 28].

Основной целью создания СГС было совершенствование механизма координации МСР для осуществления единой внешней политики Российской Федерации на международной арене. Для выполнения этой задачи были определены основные направления деятельности СГС: развитие международного сотрудничества со странами Содружества Независимых Государств, Евросоюза, АТР, Ближнего и Среднего Востока; содействие разработке законодательства по развитию приграничных связей; формирование единой информационной системы по проблемам международного сотрудничества регионов России; определение оптимальных мер по обеспечению национальной экономической безопасности в связи со вступлением РФ во Всемирную торговую организацию и др.

Президент РФ поставил перед СГС следующие задачи: это проведение консультаций и оказание информационной помощи регионам России по осуществлению международных связей; выработка рекомендаций по повышению эффективности международного сотрудничества субъектов РФ; информирование руководителей регионов по проблемам внешней политики страны и международного положения в целом, оказание помощи законодательным органам регионов в разработке правовых актов, связанных с международной деятельностью субъектов РФ и др.

В основу создания СГС была положена концепция, что сильные и процветающие регионы - это лучший фундамент единой, свободной и динамично развивающейся России [Дубровина 2011в: 29].

Основным документом, регламентирующим деятельность СГС, является Положение о Совете глав субъектов, в котором прописан механизм деятельности Совета. СГС собирается на свои заседания не реже 2 раз в год, причем заседания могут носить как открытый, так и закрытый характер.

СГС - это своего рода консультативно-совещательный орган при МИДе России. Его возглавляет председатель - министр иностранных дел РФ как руководитель ведомства, которому в соответствии с действующим законодательством поручено координировать международные связи российских регионов. Его заместителем является глава одного из регионов, входящий в тот или иной момент в состав СГС. В СГС входят руководители российских регионов по одному от каждого федерального округа. Членами СГС являются также представители соответствующих управлений Администрации Президента РФ, ряда федеральных ведомств на уровне статс-секретаря или заместителя министра, в т.ч. Министерства культуры, Министерства образования и науки, Министерства экономического развития, МВД и руководителя Государственного таможенного комитета. Такая структура обеспечивает высокую степень взаимодействия СГС с правительством и Администрацией Президента РФ $\Phi^{1}$. Состав СГС полностью обновляется раз в год. Рабочим органом СГС является секретариат, возглавляемый послом по особым поручениям, созданный на базе ДСПО МИДа России. Важнейшей составляющей структуры СГС являются рабочие группы, в которые входят не только члены Совета, но и руководители всех заинтересо-

1 Положение о Совете глав субъектов (утв. распоряжением министра иностранных дел РФ от 29.04.2003 № 17019/ГС. Доступ: http://www.mid.ru/ activity/coordinating_and_advisory_body/regulatory_ acts/-/asset_publisher/7B65cQ57DE5z/content/id/246782 
ванных регионов. При ежегодной ротации членов СГС рабочие группы имеют постоянный состав, обеспечивая преемственность в работе над приоритетными темами, которые включены в перспективный план Совета.

СГС при МИДе России сосредоточивает свое внимание на ключевых стратегических вопросах внешних связей субъектов РФ, обеспечении максимально полного учета региональных интересов при реализации внешнеполитической стратегии России. Рекомендации Совета регулярно докладываются министром иностранных дел президенту и правительству РФ.

СГС ведет публичную работу, привлекая внимание общественности к тем или иным вопросам, в т.ч. и к внешней политике. С этой целью проводятся конференции и круглые столы с участием представителей государства, общественности, экспертов и СМИ.

Анализ деятельности Совета показывает, что за время своего существования он провел большую работу, а все вопросы, которые рассматривались на его заседаниях, можно сгруппировать по следующим направлениям: организационные вопросы; участие СГС в решении вопросов в рамках международных встреч и международных организаций; территориальные направления (СНГ, Европа, АТР, Ближний и Средний Восток, Северная Африка, Антарктика и Арктика, Каспийское море и др.); вопросы функционального характера; обмен опытом; побратимские (партнерские) связи городов, работа с соотечественниками за рубежом и продвижение русского языка и образования в зарубежные страны; формирование положительного имиджа России за рубежом.

Перспективный план работы Совета, основанный на предложениях региональных руководителей, был утвержден на первом заседании СГС, которое проходило в июле 2003 г. [Дубровина 2011в: 30]. К концу 2003 г. Совет завершил организационный период и вступил в стадию практической деятельности.

За период своего существования Совет рассмотрел стратегически важные вопросы деятельности регионов России на международной арене. Рассматривались проблемы взаимодействия регионов России с Россотрудничеством, проблемы регионального взаимодействия в рамках «кавказской четверки» [Дубровина 2011a: 88], вопросы взаимодействия российских регионов с международными организациями системы $\mathrm{OOH}^{1}$, обсуждался вопрос о создании Совета межрегионального сотрудничества в форме общественной структуры для налаживания межрегиональных связей в рамках ШОС ${ }^{2}$, рассматривалась проблема активизации интеграционных процессов на пространстве Евразийского экономического союза и их влияния на социальноэкономическое положение субъектов Р $^{3}$, изучались проблемы развития двустороннего и многостороннего сотрудничества с государствами СНГ и дальнейшее укрепление действующих на пространстве СНГ интеграционных структур с участием российских регионов. Серьезное внимание уделялось вопросам сотрудничества субъектов РФ с Украиной, Белоруссией и Казахстаном 4 .

1 Об итогах XV заседания Совета глав субъектов Российской Федерации при МИД России. Доступ: http://www.mid.ru/activity/coordinating_and_advisory_body/meetings/-/asset_publisher/ o0D4RcICOGw8/content/id/259034

2 O XXVI заседании Совета глав субъектов Российской Федерации при МИД России. Доступ: http:// www.mid.ru/activity/coordinating_and_advisory_body/meetings/-/asset_publisher/ o0D4RcICOGw8/ content/id/2014138

3 O XXVII заседании Совета глав субъектов Российской Федерации при МИД России. Доступ: http:// www.mid.ru/activity/coordinating_and_advisory_body/meetings/-/asset_publisher/ o0D4RcICOGw8/ content/id/2304553

4 Об итогах IX заседания Совета глав субъектов Российской Федерации при МИД России. Доступ: http://www.mid.ru/activity/coordinating_and_advisory_body/meetings/-/asset_publisher/ o0D4RcICOGw8/content/id/370584 
В СГС обсуждалась роль межрегионального и приграничного сотрудничества субъектов РФ во внешней политике России на пространстве СНГ․ СГС большое внимание уделял перспективным направлениям сотрудничества регионов России с государствами Европы. С 2006 г. регионы России стали включать в межправительственные комиссии (МПК) по торгово-экономическому сотрудничеству РФ с государствами «группы 7». МПК оказали большую помощь в развитии международного сотрудничества регионов [Дубровина 2011a: 90]. В СГС рассматривались вопросы сотрудничества субъектов РФ со странами Евросоюза $^{2}$, укрепления позиций субъектов РФ в Азиатско-Тихоокеанском регионе $(\mathrm{ATP})^{3}$, в регионе Ближнего Востока и Северной Африки [Дубровина 2011a: 91], в Антарктике 4 , в Каспийском и Черноморском регионах.

Россия граничит с 18 странами мира на море и на суше, поэтому государство уделяет большое внимание формированию отношений добрососедства с сопредельными странами. И здесь большую роль играет приграничное сотрудничество субъектов РФ. На заседаниях СГС рассматривалось состояние и задачи законодательного регулирования приграничного сотрудничества российских регионов, обсуждались вопросы активизации межрегиональных и приграничных связей субъектов РФ в условиях финансово-экономического давления на Россию ${ }^{5}$.

На заседаниях Совета было определено, что СГС должен содействовать расширению участия субъектов РФ в выработке и реализации международной стратегии страны, усилению взаимодействия всех уровней власти, структур гражданского общества и отечественных производителей в этой области.

Постепенно СГС становится площадкой по обмену опытом осуществления международных связей регионов. Международная деятельность субъектов РФ становилась эффективным инструментом реализации ее внешнеполитических задач.

Подводя итог, следует отметить, что созданный в 2003 г. совещательный орган при МИДе России - СГС - за прошедший период проделал большую работу и стал неотъемлемой частью политического механизма реализации внешней политики на региональном уровне. Был найден новый инструмент эффективного практического взаимодействия федерального центра с регионами. С помощью СГС совершенствуется механизм координации международной деятельности регионов России, обеспечивается единая внешнеполитическая линия РФ. Совет оказывает консультативную, информационную и методическую помощь регионам страны по развитию ими международных связей, информирует руководителей субъектов по вопросам международной деятельности России, особенно по тем, которые затрагивают интересы российских регионов. Благодаря Совету улучшилось дипломатическое сопровождение международных связей регионов.

1 Об итогах XIII заседания Совета глав субъектов Российской Федерации при МИД России. Доступ: http://www.mid.ru/activity/coordinating_and_advisory_body/meetings/-/asset_ publisher/ o0D4RcICOGw8/content/id/293558

2 Об итогах XVIII заседания Совета глав субъектов Российской Федерации при МИД России. Доступ: http://www.mid.ru/activity/coordinating_and_advisory_body/meetings/-/asset_ publisher/ o0D4RcICOGw8/content/id/293558

3 O XXI заседании Совета глав субъектов Российской Федерации при МИД России. Доступ: russiatourism.ru/news/2313

4 Об итогах XIX заседания Совета глав субъектов Российской Федерации при МИД России. Доступ: http://www.mid.ru/activity/coordinating_and_advisory_body/meetings/-/asset_ publisher/ o0D4RcICOGw8/content/id/154800

5 O XXIV заседании Совета глав субъектов Российской Федерации при МИД России. Доступ: http:// www.mid.ru/activity/coordinating_and_advisory_body/meetings/-/asset_publisher/ o0D4RcICOGw8/ content/id/789682 
За 15 лет существования СГС был создан стройный механизм, позволивший расширить участие регионов в выработке и реализации международной стратегии РФ, придать постоянный и системный характер внешней деятельности субъектов РФ. Расширение международных связей российских регионов дало возможность приблизить внешнюю политику России к интересам рядовых граждан, способствовать улучшению условий их жизни. Тем самым решалась одна из ключевых задач внешней политики - создание благоприятных внешних условий для развития России ${ }^{1}$.

\section{Список литературы}

Бажанов Е.П., Бажанова Н.Е. 2011. Международные отношения в ХХІ веке. М.: Восток-Запад. 166 с.

Василенко И.А. 2009. Политическая философия. М.: Инфра-М. 318 с.

Дубровина О.Ю. 2011а. Деятельность Совета глав субъектов Российской Федерации МИД России на внешнеполитическом направлении в 20052007 гг. - Сборник научных статей МГУ им. Ломоносова. LOGOS-2011. М.: МГУ им. М.В. Ломоносова. С. 86-92.

Дубровина О.Ю. 2011б. Политический механизм осуществления международных связей регионов государств. - Власть. № 10. С. 74-77.

Дубровина О.Ю. 2011в. Совет глав субъектов Российской Федерации при МИД России и его роль в реализации внешнеполитической стратегии государства (2003-2005 гг.). - Сборник научных статей МГУ им. Ломоносова. LOGOS2011. М.: МГУ им. М.В. Ломоносова. С. 28-34.

Дубровина О.Ю. 2013а. Региональное измерение внешней политики: сущность и содержание. - Власть. № 3. С. 76-81.

Дубровина О.Ю. 2013б. Региональное измерение внешней политики: сущность и содержание. - Сибирский международный. № 16. С. 24-33.

Дубровина О.Ю. 2014а. Политический механизм регионального измерения внешней политики государств: организационная и функциональная составляющие. - Власть. № 9. С. 68-72.

Дубровина О.Ю. 2014б. Политический механизм регионального измерения внешней политики государств: понятие, структура, регулятивная составляющая политического механизма. - Власть. № 8. С. 57-62.

Плотникова О.В. 2014. Влияние глобализации и регионализации на международное сотрудничество регионов государств. - Сибирский межжународный. № 16. С. 5-8.

Плотникова О.В. 2015. Регионы России, их типы и особенности. - Сибирский международный. № 17. С. 37-44.

Плотникова О.В., Дубровина О.Ю. 2016а. Международные связи регионов государств: характеристика и особенности. М.: Норма. 192 с.

Плотникова О.В., Дубровина О.Ю. 2016б. Типологизация регионов России в контексте проблем международного сотрудничества и регионализации. - Вестник Новосибирского государственного педагогического университета. № 3(31). С. 68-78.

Цыганков П.А. 2010. Теория человеческой безопасности: политические последствия, уроки для России. - Вестник Московского университета. Cер. 12. Политические науки. № 4. С. 78-83.

Bertalanffy L., von. 1968. General System Theory. N.Y.: George Braziller, lnc. 289 p.

Braillard Ph., Djalili M.-R. 1988. Les relations internationale. Paris: Presses Universitaires de France. 128 p.

\footnotetext{
1 Там же.
} 
Briol F.1997. Decentralisation territoriale et cooperation internationale. P.: I'Harmattan. $395 \mathrm{p}$.

Claisse Y. 1994. Le droit de la cooperation decentralisee. Coll. Travaux et recherches, Pantheon-Assas (Paris II): L.G.D.J. 287 p.

Haegi C. 1995. The Europe of Region. Geneve: Georg Editeur SA. 298 p.

Hoffmann S. 1961. Theory et relations internationals Revue francaise de science politique. Vol. XI. 600 p.

Kaplan A. 1964. The Language of Inquiry. N.Y. 502 p.

Michelmann H. 1993. The Federal Republic of Germany. - Federalism and International Relations: The Role of Subnational Units. N.Y.

Rassett B., Starr H. 1981. World Politics. Menu for Choice. San-Francisco. 405 p.

\section{THE FOREIGN MINISTRY'S COUNCIL OF HEADS OF CONSTITUENT ENTITIES OF THE RUSSIAN FEDERATION AS A MECHANISM FOR COORDINATING REGIONAL INTERNATIONAL RELATIONS: HISTORICAL AND METHODOLOGICAL ASPECTS OF THE PROBLEM}

\footnotetext{
Abstract. This article is devoted to the problem of activities of the Foreign Ministry's Council of Heads of Constituent Entities of the Russian Federation, which is little represented in the scientific literature. Being established in 2003, the Council is an important mechanism for the interaction of the federal center with the regions of Russia. Its goal was to improve the coordination of the international relations of the regions for the implementation of a common foreign policy of the Russian Federation in the international arena.

The article discusses the main directions, tasks, forms, methods and problems of the Council's activities, shows the results of its work against the background of a common foreign policy of the Russian Federation in the international arena.

Keywords: Foreign Ministry's Council of Heads of Constituent Entities of the Russian Federation, international relations of regions of Russia, foreign policy of Russian Federation, globalization, advisory body under the Ministry of Foreign Affairs of Russia, mechanism for implementing international strategy, mechanism for implementing international relations of regions of Russia
} 